\title{
THE EFFECT OF DIFFERENT SOWING TIME AND HARVESTING STAGES ON THE HERBAGE YIELD AND QUALITY OF QUINOA (Chenopodium quinoa Willd.)
}

\author{
Suleyman TEMEL ${ }^{1 *}$, Savas YOLCU ${ }^{2}$ \\ ${ }^{1}$ Igdir University, Faculty of Agriculture, Department of Field Crops, Igdir, TURKEY \\ ${ }^{2}$ Aydin Directorate of Provincial Agriculture and Forestry, Aydin, TURKEY \\ *Corresponding author: stemel33@hotmail.com
}

Received: 25.12 .2019

\begin{abstract}
Knowing the proper sowing and harvesting periods in plants cultivated as roughage resource is very important for achieving high yield and quality performance. However, studies on sowing and harvesting times in quinoa grown for hay production are almost non-existent. In this study, the effects of different sowing (middle of March, end of March, beginning of April and middle of April) and harvesting (the end of vegetative stage, beginning of the flowering and the full flowering) periods on herbage yield and quality performance of quinoa's Mint Vanilla variety were investigated. Research was conducted under irrigated conditions of Igdir during 2017-2018. The experimental design was split plot design with three replications. According to statistical analysis, higher plant height, dry matter and crude protein yields were obtained from plants sown at the end of March and harvested at full flowering. The highest crude protein ratio, dry matter digestible and relative feed value with the lowest neutral detergent fibre and acid detergent fibre ratios were observed in plants sown in the late period and harvested at the early period. As a result, crude protein and digestibility values were generally increased while dry matter and crude protein yields were decreased with late sowing and harvesting.
\end{abstract}

Keywords: Development periods, Igdir, Irrigated conditions, Mint Vanilla, Nutritional values

\section{INTRODUCTION}

Quinoa (Chenopodium quinoa Willd.), a member of Amaranthaceae family, is a highly nutritious food product that has been cultivated for its seeds in South America for over 7000 years (Cusack, 1984; Pearsall, 1992). Quinoa can be easily grown under unfavorable climate and soil conditions where many cultivars cannot be economically produced (Jacobsen et al., 2003; Sanchez et al., 2003; Bhargava et al., 2006; González et al., 2009). Moreover, the fact that quinoa seeds have higher protein content than many cereal groups (Martínez, 2015) has led to an increase in interest in the plant (Krivonos, 2013; Bazile et al., 2015). Undoubtedly, the choice of variety for as well as knowledge of the appropriate sowing and harvesting periods are of great importance for a profitable production in cultivation, in terms of achieving high yield and quality performances from the unit area. Quinoa is generally cultivated for its seeds which are utilized as human food. Thus, a great majority of agronomic studies conducted on the plant includes evaluations on seed performance (Geren et al., 2014; Kir and Temel, 2016; Kir and Temel, 2017; Tan and Temel, 2017a; Tan and Temel, 2018; Casini, 2019). In the studies carried out, it was revealed that seed performances were significantly affected by sowing and harvesting periods and, as a consequence, sowing or harvesting should be carried out at an early or late period (Risi and Galwey, 1991; Aguilar and Jacobsen, 2003; Munir, 2011; Geren et al., 2014).

Although quinoa is cultivated for its seeds, it is also grown for its hay as a source of fodder (Galwey, 1989; Jacobsen and Stolen, 1993; Sigsgaard et al., 2008; Bertero and Ruiz, 2010; Iqbal, 2015). The plant can produce high herbage yields per unit area (15665-17180 kg ha-1) (Tan and Temel, 2017b; Temel and Surgun, 2019) and quinoa hay is especially preferred by cattle (FAO, 1994). Moreover, crude protein content of quinoa hay is between $13 \%$ and $22 \%$ and dry matter digestibility is between $63 \%$ and $69 \%$, which are both desired levels (Van Schooten and Pinxterhuis, 2003). Because of such properties, quinoa can be viewed to have a great potential for benefiting from the production in marginal areas, overcoming the roughage gap and supplying the daily nutritional requirements of animals. However, in order to obtain the desired yield and quality performances in the quinoa plant grown for hay production purposes, it is necessary to establish appropriate sowing and harvesting periods according to ecological conditions of the region where it will be grown. 
The quantity and quality of the hay obtained from the plants grown for the purpose of fodder production is directly related to the sowing and harvesting times (Buxton, 1996; Geren and Alan, 2012). Although variations can be seen as to the ecological conditions of the region of cultivation, in general, increases in hay yields and decreases in nutritional values have been determined with the progress of development period in plants (Temel and Tan, 2002; Gulsen et al., 2004). Moreover, in early sowing, plants stay in the field for a longer time, compared to late-sown plants, and benefit from the environmental conditions in an optimum way. As a consequence, yields may be high while the quality values are low. However, studies on which the sowing and harvesting times were tested together in the quinoa plant grown for hay production purposes were almost nonexistent in the world and in Turkey. In fact, it was reported in a few studies conducted on the subject that quinoa hay yield and quality were significantly affected by sowing and harvesting periods (Hirich et al., 2014; Rames, 2016; Uke, 2016).

Although it has been shown that sowing and harvesting periods of quinoa differ according to the regions, it can be said that few studies conducted on the subject are inadequate, since sowing and harvesting periods may significantly vary as to ecological conditions of the cultivation regions. In addition, to what degree yield and quality properties of quinoa cultivated for hay production purposes affected by different sowing and harvesting periods must be completely cleared out. In this respect, such studies on quinoa are important to determine optimum yield and quality performance under different ecological conditions and to extend quinoa farming. Thus, a research study was planned to determine appropriate sowing and harvesting periods in quinoa cultivated under irrigated conditions of Igdir province for achieving high hay yield and quality properties.

\section{MATERIALS AND METHODS}

The study was conducted between 2017 and 2018 under irrigated conditions in Igdir province located in the Northeast of Turkey. When some climatic data of the experimental area were examined, average temperature values of the growing season of 2017 and 2018 were measured as $18.2 \mathrm{C}^{0}$ and $19.5{ }^{\circ} \mathrm{C}$, relative humidity $47.9 \%$ and $52.8 \%$, total rainfall amounts were $100.0 \mathrm{~mm}$ and $141.7 \mathrm{~mm}$, respectively. According to long-years average, average temperature, relative humidity and total precipitation amount are measured as $18.41{ }^{\circ} \mathrm{C}, 48.6 \%$ and $166.4 \mathrm{~mm}$, respectively (Table 1) (Anonymous, 2019). According to these data, the experiment was conducted under relatively more arid conditions since lower precipitation was observed according to long-years averages in the cultivation period within which the research conducted. Adequate amounts of soil samples (0$30 \mathrm{~cm}$ ) were taken in both research years and according to the results of the analyses, it was found that soils were found to be non-saline, slightly alkaline, with mild lime content, low available phosphorus level and high potassium content. However, the experiment site in 2017 had clay-loam soil structure with a good organic matter content, while 2018 research site was classified as clay soil with medium-level organic matter content (Table 2) (Kacar, 2012).

Table 1. Some climatic characteristics of the research area*

\begin{tabular}{|c|c|c|c|c|c|c|c|c|c|}
\hline \multirow{2}{*}{ Aylar } & \multicolumn{3}{|c|}{ Temperature $\left({ }^{0} \mathrm{C}\right)$} & \multicolumn{3}{|c|}{ Precipitation $(\mathrm{mm})$} & \multicolumn{3}{|c|}{ Relative humid (\%) } \\
\hline & LYA $* *$ & 2017 & 2018 & LYA & 2017 & 2018 & LYA & 2017 & 2018 \\
\hline March & 8.5 & 6.7 & 12.3 & 19.0 & 11.4 & 16.5 & 47.7 & 59.9 & 51.9 \\
\hline April & 14.4 & 13.4 & 14.2 & 43.9 & 18.1 & 18.2 & 50.5 & 47.2 & 49.6 \\
\hline May & 18.4 & 18.6 & 18.4 & 57.2 & 57.0 & 69.3 & 56.2 & 54.0 & 65.5 \\
\hline June & 23.6 & 24.2 & 23.4 & 30.5 & 8.2 & 31.8 & 46.1 & 42.9 & 54.5 \\
\hline July & 26.9 & 28.0 & 29.2 & 15.8 & 5.3 & 5.9 & 42.7 & 35.4 & 42.4 \\
\hline Total/Mean & 18.4 & 18.2 & 19.5 & 166.4 & 100.0 & 141.7 & 48.6 & 47.9 & 52.8 \\
\hline
\end{tabular}

*MGM, 2019; ** LYA: Long Year Average

Table 2. Some chemical and physical properties of the study area soils

\begin{tabular}{|c|c|c|c|c|c|c|c|}
\hline Years & Texture class & $\begin{array}{c}\text { Organic matter } \\
(\%)\end{array}$ & $\begin{array}{c}\mathrm{CaCO}_{3} \\
(\%)\end{array}$ & $\begin{array}{c}\mathrm{EC} \\
\left(\mathrm{dS} \mathrm{m}^{-1}\right)\end{array}$ & pH & $\begin{array}{c}\mathrm{P}_{2} \mathrm{O}_{5} \\
\left(\mathrm{~kg} \mathrm{ha}^{-1}\right)\end{array}$ & $\begin{array}{c}\mathrm{K}_{2} \mathrm{O} \\
\left(\mathrm{kg} \mathrm{ha}^{-1}\right)\end{array}$ \\
\hline 2017 & Clay-loam & 3.08 & 10.57 & 1.42 & 7.60 & 53.3 & 1368.9 \\
\hline 2018 & Clay & 2.10 & 10.18 & 1.50 & 7.85 & 1.10 & 536.8 \\
\hline
\end{tabular}

Mint Vanilla variety of quinoa (Chenopodium quinoa Willd.), which was determined to have the highest hay yield as a result of a project by TUBITAK (The Scientific and Technological Research Council of Turkey), was used as material in the study. Four different sowing dates were tested in the research and 10-day intervals between sowings were carefully observed. Hence, the first sowings $\left(\mathrm{ST}_{1}\right)$ were conducted on March 15 , the second sowings
$\left(\mathrm{ST}_{2}\right)$ on March 25 , the third sowings $\left(\mathrm{ST}_{3}\right)$ on April 5 and the fourth sowings $\left(\mathrm{ST}_{4}\right)$ were conducted on April 15 of the first trial year. In the second trial year (2018), $\mathrm{ST}_{1}$, $\mathrm{ST}_{2}, \mathrm{ST}_{3}$ and $\mathrm{ST}_{4}$ were conducted on March 16, March 27, April 7 and April 19, respectively. In addition, seed bed temperatures (at $0-10 \mathrm{~cm}$ depth) were measured and recorded. Soil temperatures according to trial years were recorded as $6-8{ }^{\circ} \mathrm{C}$ at $\mathrm{ST}_{1}, 9-11^{\circ} \mathrm{C}$ at $\mathrm{ST}_{2}, 15-16{ }^{\circ} \mathrm{C}$ at $\mathrm{ST}_{3}$ 
and as $16-18{ }^{\circ} \mathrm{C}$ at $\mathrm{ST}_{4}$. Harvesting was carried out at the end of vegetative period $\left(\mathrm{CS}_{1}\right)$, at the beginning of the flowering $\left(\mathrm{CS}_{2}\right)$ and at the full flowering period $\left(\mathrm{CS}_{3}\right)$ to determine the effect of plant development periods on the quantity and quality of the obtained hay. In this respect, the first harvest was carried out at the period during when first panicles were seen on plants, the second harvest was carried out when the buds on panicles began to flower and the third harvest was done when the flowering on panicles was completed to a large extent.

The research was designed according to a split plot in randomized block design with three replicates. Sowing times were established on the main plots and harvesting times were placed on the subplots. Area of each subplot in the research was set as $7.35 \mathrm{~m}^{2}(3 \mathrm{~m} \times 2.45 \mathrm{~m})$ and a 2meter space was left between all plots and blocks. Hole sowing method was used for sowing. Seeds were sown into furrows opened by a marker into mellowed soil at 1.5-2.0 sowing depth with $35 \mathrm{~cm}$ row spacing and $15 \mathrm{~cm}$ intra-row spacing (plant-to-plant distance). The soil was fertilized with $75 \mathrm{~kg}$ of pure $\mathrm{N}$ ( $21 \%$ ammonium sulphate) and $80 \mathrm{~kg}$ pure $\mathrm{P}_{2} \mathrm{O}_{5}$ (39-41\% triple super phosphate) per ha during the preparation of seedbeds. Moreover, an additional $50 \mathrm{~kg}$ of pure $\mathrm{N}$ per ha area was also applied when plant height reached 30-40 cm (Geren, 2015). Soil humidity was measured by Soil Water Potential device and the plants were irrigated when $50 \%$ of field capacity was depleted. Sufficient amount of water was given to the plants by drip irrigation until the field regains capacity. Weeds formed between plots and blocks were controlled by pulling and hoeing and this process was repeated three times during the growth of the plants. In addition, insecticide was applied to insects seen at 2-4-leaf period.

At the time of harvest, the rows on the sides and $0.5 \mathrm{~m}$ parts from the heads of the plots were taken and the measurements were carried out in the remaining area. Plant heights were determined by measuring the distance between the root collar and the top of 10 plants selected randomly from each plot. Plants in the harvest area were cut at $7.5 \mathrm{~cm}$ stubble height and fresh weights were measured. Then, $1000 \mathrm{~g}$ representative fresh hay samples were taken and dried at a drying oven set at $70{ }^{\circ} \mathrm{C}$ until the weights of samples are stabilized. After this, measured dry matter weights were proportioned by fresh hay yields to obtain dry matter yields. Determination of total nitrogen contents in ground hay samples was carried out according to Micro Kjeldahl method and nitrogen ratios then multiplied by the quotient 6.25 to determine crude protein ratios (AOAC, 1997). Crude protein yields, dry matter yields and crude protein ratios of the plants were determined by multiplying. Neutral detergent fibre (NDF) an acid detergent fibre (ADF) ratios were determined by the method developed by Van Soest et al. (1991). Dry matter digestibility (DMD) and relative feed values (RFV) of the fodder samples were determined by equations suggested by Sheaffer et al. (1995) (DMD\% = 88.9[0.779 x ADF\%], and RFV = [DMD x DMI] / 1.29). DMI in the RFV formula was calculated by the equation "Dry Matter Consumption \% $=120$ / NDF\%".
Data from the research were subjected to variance analysis according to split plots in randomized block design repeated two years by using JMP 5.1 statistical software package and comparison of the means that were found significant was conducted according to $\operatorname{LSD}_{(0.05)}$ test.

\section{RESULTS AND DISCUSSION}

Data presentation and discussion were only carried out for interactions found to be significant. That is; binary interactions were not elaborated separately in the parameters in which triple interactions were found significant, and main factors were not considered separately in the parameters in which binary interactions were significant.

\section{Plant height}

In this study in which different sowing and harvesting times were tested in quinoa plant, the effect of year $x$ sowing time interaction on the plant height was found significant $(\mathrm{P} \leq 0.01)$. The highest plant height $(126.1 \mathrm{~cm})$ was observed in the first sowing $\left(\mathrm{ST}_{1}\right)$ in 2017 while the lowest value $(51.3 \mathrm{~cm})$ was determined in the last sowing $\left(\mathrm{ST}_{4}\right)$ in 2017 (Figure 1). In this respect, Hirich et al. (2014) stated report that increases in temperature shorten the development time of quinoa. Thus, in late sowing, plants may reach harvesting maturity without adequate vegetative development since plants are exposed to increasing temperatures and light intensity. As a result, plant heights in late sowings can be shorter. Particularly in 2017, while the rate of decrease in plant height $(57.98 \%)$ was quite high from the second sowing to the last sowing time. The fact that the rate of decrease was very low in $2018(3.52 \%)$ may be a cause of the significance of year $\mathrm{x}$ sowing time interaction. It is considered that changing annual temperatures, rainfall amount and distribution were effective on the differences in plant heights as to sowing times (Table 1). Hence, Geren et al. (2014) and Ramesh (2016) have shown that environmental factors such as temperature and precipitation played an important role in plant height. Moreover, it was also reported in studies on quinoa that plant height varied according to years depending on changing climate conditions and that plant height was decreased with delays in sowing time (Fernando et al., 2012; Ramesh, 2016; Uke, 2016).

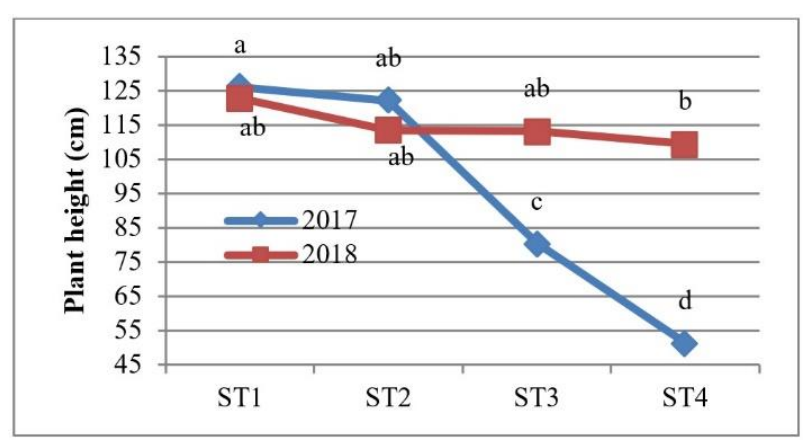

Figure 1. The change in plant height according to sowing times and years. Plots followed by the different letters are significant at $\mathrm{P} \leq 0.01$. ST: Sowing time 


\section{Dry matter yield}

Dry matter yield was found to be significantly affected by year $\mathrm{x}$ sowing time $\mathrm{x}$ harvesting period interaction and the highest yield of $22267 \mathrm{~kg} \mathrm{ha}^{-1}$ was obtained from plots sown in March $25\left(\mathrm{ST}_{2}\right), 2017$ and harvested at full flowering period $\left(\mathrm{CS}_{3}\right)$. On the other hand, the lowest dry mater yield was obtained from the plots sown in the late period (April 15) and harvested at the end of vegetative period with $5328 \mathrm{~kg} \mathrm{ha}^{-1}$ (Table 3). Looking at Table 3, while dry matter yield in the second harvest of the sowings at the end of March in 2017 increased by $20.00 \%$, it can be seen that there is a $2.62 \%$ decrease in the same group in 2018. Moreover, the fact that dry matter yield increases of the third harvest of plants sown in the second period $\left(\mathrm{ST}_{2}\right)$ are higher in $2017(31.33 \%)$ than in 2018 $(3.50 \%)$ resulted in the significance of the triple interaction. This may be a result of different levels of influence of sowing and harvesting times on such plant development phases as germination, seedling, vegetative and generative periods due to annual changes in climate and soil conditions. It was also reported in previous studies that higher dry matter yields were obtained in quinoa sown late and harvested in the early period (Hirich et al., 2014; Ramesh, 2016; Uke, 2016). As a matter of fact, since vegetation period was longer in early sowings and late harvests, available resources such as water, light and nutritional elements can be used more effectively by the plants. As a result, the ratio of structural carbohydrates increases, new tissues are formed and significant increases in hay yields may be observed (Temel and Tan, 2002). On the other hand, optimum seed germination in quinoa occurs when soil temperature is $8-10{ }^{\circ} \mathrm{C}$ (Jacobsen et al., 1999). This affects number of plants in harvest and, thus, the yield (Geren et al., 2014). In our present study, it was seen that the most suitable soil temperature for germination was measured in March 25 sowings.

Table 3. The dry matter yield and relative feed value of quinoa in different sowing time and cutting stages

\begin{tabular}{|c|c|c|c|c|c|c|c|}
\hline \multirow[t]{2}{*}{ Years } & \multirow{2}{*}{$\begin{array}{l}\text { Sowing } \\
\text { times }\end{array}$} & \multicolumn{3}{|c|}{$\begin{array}{c}\text { Dry matter yield }\left(\mathrm{kg} \mathrm{ha}^{-1}\right) \\
\text { Cutting stages }\end{array}$} & \multicolumn{3}{|c|}{$\begin{array}{l}\text { Relative feed value } \\
\text { Cutting stages }\end{array}$} \\
\hline & & $\mathbf{C S}_{1}$ & $\mathbf{C S}_{2}$ & $\mathrm{CS}_{3}$ & $\mathbf{C S}_{1}$ & $\mathbf{C S}_{2}$ & $\mathrm{CS}_{3}$ \\
\hline \multirow{4}{*}{ 흘 } & $\mathbf{S T}_{1}$ & $9320 \mathrm{k}-\mathrm{m}$ & $12710 \mathrm{gh}$ & $16955 \mathrm{c}$ & $171.4 \mathrm{~h}-\mathrm{j}$ & $157.9 \mathrm{j}-\mathrm{k}$ & $143.8 \mathrm{k}$ \\
\hline & $\mathbf{S T}_{2}$ & $14207 \mathrm{~d}-\mathrm{g}$ & $15253 \mathrm{~d}$ & $22267 \mathrm{a}$ & $189.8 \mathrm{e}-\mathrm{h}$ & $174.0 \mathrm{~g}-\mathrm{j}$ & $158.61-\mathrm{k}$ \\
\hline & $\mathbf{S T}_{3}$ & $8496 \mathrm{~lm}$ & $12284 \mathrm{~h} 1$ & 13437 d-h & $221.7 \mathrm{~b}-\mathrm{d}$ & $194.6 \mathrm{ef}$ & $176.9 \mathrm{f}-\mathrm{j}$ \\
\hline & $\mathrm{ST}_{4}$ & $5328 n$ & $8056 \mathrm{~m}$ & $9327 \mathrm{~lm}$ & $227.3 b$ & $219.3 \mathrm{~b}-\mathrm{d}$ & $194.6 \mathrm{ef}$ \\
\hline \multirow{4}{*}{ 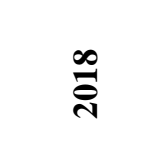 } & $\mathbf{S T}_{1}$ & $13291 \mathrm{f}-\mathrm{h}$ & $15067 \mathrm{de}$ & $18153 \mathrm{bc}$ & $226.5 \mathrm{bc}$ & $193.3 \mathrm{e}-\mathrm{g}$ & $170.9 \mathrm{~h}-\mathrm{j}$ \\
\hline & $\mathbf{S T}_{2}$ & 10183 jk & $14672 d-f$ & $18789 \mathrm{~b}$ & $252.0 \mathrm{a}$ & $180.8 \mathrm{f}-\mathrm{h}$ & $174.7 \mathrm{f}-\mathrm{j}$ \\
\hline & $\mathbf{S T}_{3}$ & 8614 k-m & $10980 \mathrm{ij}$ & 13743 e-h & $201.6 \mathrm{de}$ & $178.3 \mathrm{f}-1$ & $169.6 \mathrm{~h}-\mathrm{j}$ \\
\hline & $\mathrm{ST}_{4}$ & $8095 \mathrm{~m}$ & $9632 \mathrm{j}-\mathrm{m}$ & $9894 \mathrm{j}-1$ & 206.4 c-e & $193.9 \mathrm{e}-\mathrm{g}$ & $188.0 \mathrm{e}-\mathrm{h}$ \\
\hline $\operatorname{LSD}_{(0.05)}$ & & \multicolumn{3}{|c|}{ Y x ST х CS: $1641 *$} & \multicolumn{3}{|c|}{ Y x ST x CS: $20.4^{*}$} \\
\hline
\end{tabular}

*: significant at $\mathrm{P} \leq 0.05$. Means followed by the same letters are not different for $\mathrm{P} \leq 0.05$ according to LSD test. Y: Year, ST: Sowing time, CS: Cutting stage

\section{Crude protein ratio}

Effects of year $\mathrm{x}$ harvesting time and year $\mathrm{x}$ sowing time interactions on crude protein ratio of quinoa have shown statistically significant differences $(\mathrm{P} \leq 0.01)$. As for year $\mathrm{x}$ harvesting time interaction, the highest crude protein ratio $(22.28 \%)$ was observed in the plots harvested at the end of vegetative period in 2018 , but the lowest ratio $(17.37 \%)$ was observed in the harvest at the full flowering period in the same year (Figure 2). This may be a result of to increased vegetative growth in plants due to the fact that the amount of precipitation especially in May and June in 2018 was considerably higher than in the same months of 2017 (Table 1). As a matter of fact, Buxton (1996) stated that the ratio of leaves in plants was higher in early development periods and therefore the crude protein content was higher. While the decrease in crude protein content in the second harvesting time in comparison with the first harvesting time in 2017 was quite low $(4.49 \%)$, the fact that the drop in 2018 was greater $(18.18 \%)$ may be a reason for the significance of year $\mathrm{x}$ harvest time interaction. In general, the number of young cells in the early development of plants is more intense, which increases protein synthesis (Kacar et al., 2006). However, the ratio of extracellular structural carbohydrates (cellulose and lignin) increases due to the decrease in leaf / stem ratio in advanced development periods and crude protein content decreases as plant development advances (Kutlu, 2008; Gokkus, 2009). Hence, it was reported that the quinoa leaves are rich in protein and its stems are poor in protein (Buxton, 1996). In addition, in another study on quinoa, it was reported that the rate of crude protein was decreased significantly as the harvesting time was delayed and the lowest value $(11.7 \%)$ was obtained during the seed bulking stage (Uke, 2016). 

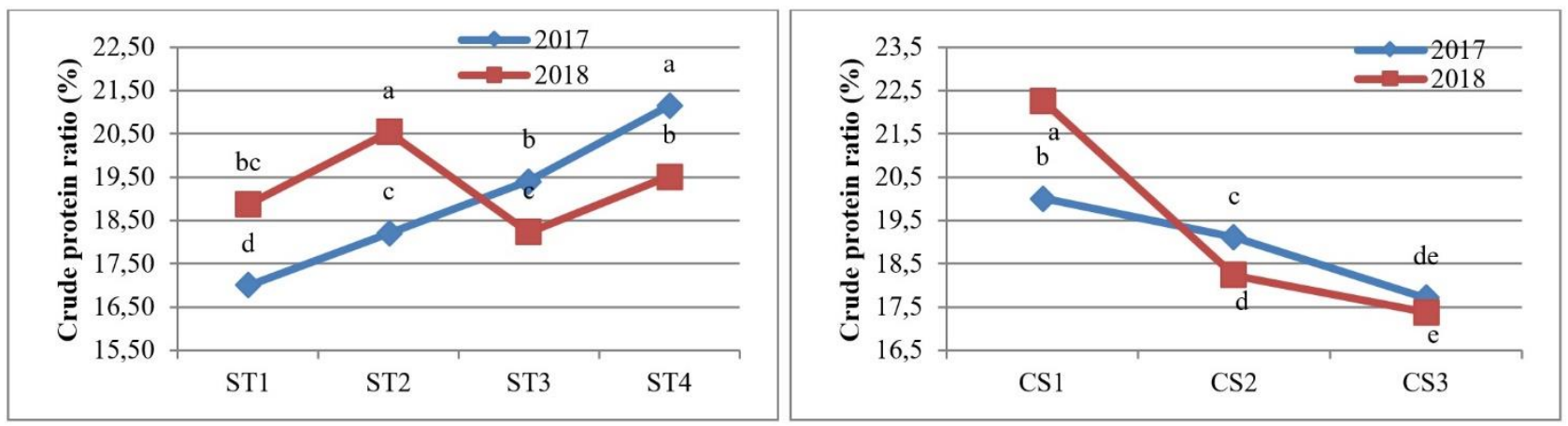

Figure 2. The effect of Y x ST and Y x CS interaction on the crude protein ratio. Plots followed by the different letters are significant at $\mathrm{P} \leq 0.01$. Y: Year, ST: Sowing time, CS: Cutting stage

Year $\mathrm{x}$ sowing time interaction was another significant factor affecting crude protein ratio and the highest crude protein ratios were obtained from the plants sown in April 15, 2017 and March 25, 2018 with $21.16 \%$ and 20.54\%, respectively. The lowest crude protein ratio was determined in the plants sown in March 15, 2017 $(17.00 \%)$ (Figure 2). While there were continuous increases in crude protein content in 2017 as the sowings were delayed, it was first increased, then decreased and then increased again in 2018. In addition, while crude protein ratio was increased by $6.59 \%$ in $\mathrm{ST}_{3}$ in 2017 , it was decreased by $11.25 \%$ in 2018 . This is resulted in the significance of year $\mathrm{x}$ sowing time interaction. Such changes in crude protein content may be caused by differences in plant heights according to years and sowing times. In general, plants tend to come to the cutting maturity without showing sufficient growth (vegetative growth) due to increased air temperatures in late sowings. This may have caused the plant height to be low in late sowings and thus the leaf / stem ratio to be higher than early sowings. Hence, in 2017, the highest plant height $(126.1 \mathrm{~cm})$ was determined at the first sowing time and the lowest plant height was determined at the fourth sowing time $(51.3 \mathrm{~cm}$ ) (Figure 1). As known, the increase in plant height increases the ratio of stems rich in structural carbohydrates such as cellulose and lignin. Increasing the stem/leaf ratio, on the other hand, decreases the rate of non-structural carbohydrates such as protein (Buxton, 1996).

\section{Crude protein yield}

All of the binary interactions were found to be statistically significant for crude protein yield. In year $\mathrm{x}$ sowing time interaction, the highest crude protein yields were recorded in $\mathrm{ST}_{2}$ of $2017\left(3107.7 \mathrm{~kg} \mathrm{ha}^{-1}\right)$ with $\mathrm{ST}_{1}$ $\left(2891.6 \mathrm{~kg} \mathrm{ha}^{-1}\right)$ and $\mathrm{ST}_{2}$ of $2018\left(2926.9 \mathrm{~kg} \mathrm{ha}^{-1}\right)$. The lowest crude protein yield was observed in $\mathrm{ST}_{4}$ of 2017 with $1526.8 \mathrm{~kg}$ per hectare (Figure 3). While crude protein yield increased by $44.04 \%$ in $\mathrm{ST}_{2}$ of 2017 in comparison with $\mathrm{ST}_{1}$ of the same year, it was increased by $1.22 \%$ in 2018 , which resulted in the significance of year $\mathrm{x}$ sowing time interaction. Differences in dry matter yields and crude protein ratios as to sowing times may be caused by the crude protein yield to be low or high. Because crude protein yield is a product of crude protein ratio and dry matter yield values. In the present study, it was seen that highest dry matter yields were obtained in the second sowings of 2017 (Table 3). Therefore, crude protein yields may be high. In the studies carried out with different forage crop species, it was reported that the crude protein yields decreased significantly due to the low dry matter yields obtained from the unit area in late sowings (Temel and Tan, 2002).

Another significant interaction for crude protein yield is year $\mathrm{x}$ harvesting period. The highest crude protein yields were obtained at the last harvesting periods of the both trial years while the lowest value was obtained from the harvest carried out at the end of the vegetative period $\left(\mathrm{CS}_{3}\right)$ in 2017 (Figure 3). The fact that crude protein yield at $\mathrm{CS}_{3}$ in $2018\left(2228.2 \mathrm{~kg} \mathrm{ha}^{-1}\right)$ was greater than that of $\mathrm{CS}_{3}$ in $2017\left(1839.1 \mathrm{~kg} \mathrm{ha}^{-1}\right)$ and that crude protein yields in other periods showing differences were the reasons for the significance of the year $\mathrm{x}$ harvesting time interaction. This may be resulting from dry matter yield and, particularly, crude protein ratio of $\mathrm{CS}_{1}$ of 2018 being greater than those in 2017 (Figure 2). Because crude protein ratio is one of the parameters used in calculating crude protein yield. Generally, in late harvest periods, although the crude protein content decreases, dry matter yields obtained from the unit area are generally higher (Temel and Tan, 2002). In our current study, the high yields of dry matter in the late harvest period may have caused this.

Sowing time $\mathrm{x}$ harvesting time interaction was found to be significant for crude protein yield at $1 \%$ significance level in the study. According to this, the highest crude protein yield was obtained from the plots which were sown in the second period (March 25) and harvested during the full flowering period. The lowest crude protein yield was determined from the plots harvested on April 15 $\left(\mathrm{ST}_{4}\right)$ and harvested at the end of the vegetative period $\left(\mathrm{CS}_{1}\right)$ (Figure 3). When Figure 3 was examined, it can be seen that percentage changes in crude protein yield according to sowing times in the first and second harvest periods were generally found to be low and similar. However, the fact that this change was much higher in the third harvest period of the second sowing caused the interaction of sowing time $\mathrm{x}$ harvest time to be significant. In general, since dry matter yields obtained from the unit area was generally high in plants sown early and harvested late, the crude protein yields were also high (Temel and 
Tan, 2002). In the present study, high yields of dry matter in the plots cultivated in the second period and harvested in the last period may have caused this difference.

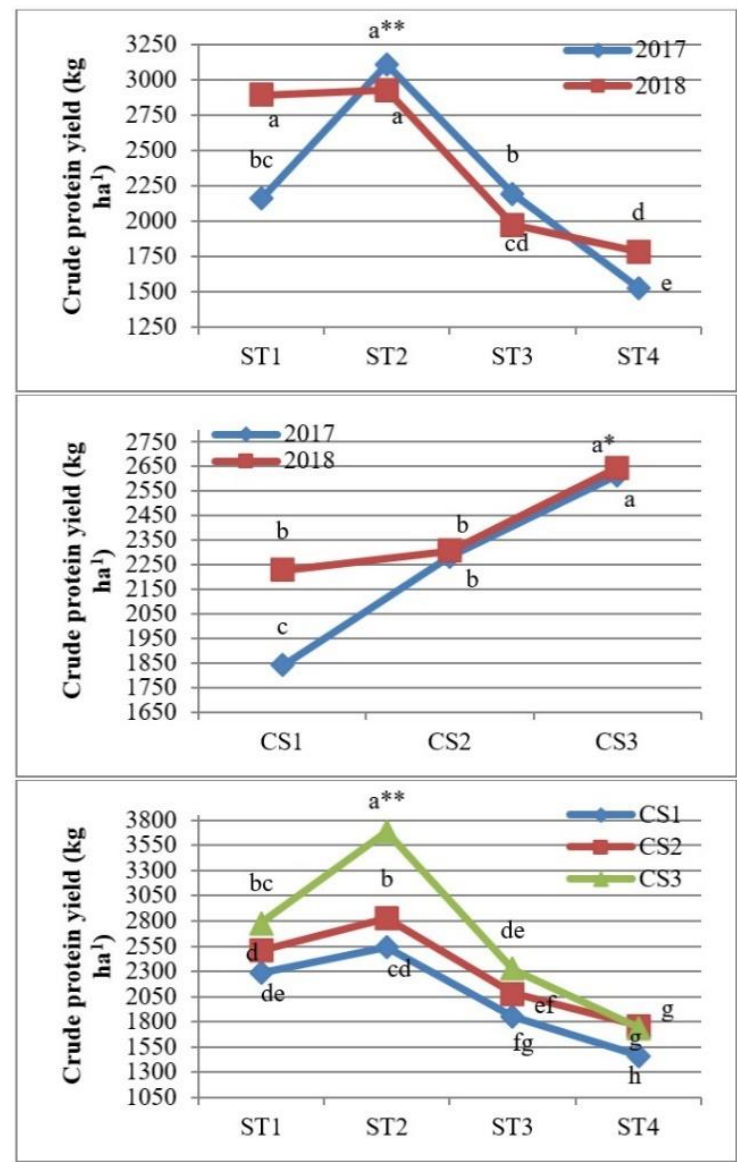

Figure 3. The effect of $\mathrm{Y} x \mathrm{ST}, \mathrm{Y} \times \mathrm{CS}$ and ST $\mathrm{x}$ CS interaction on the crude protein yield. ** and * plots followed by the different letters are significant at $\mathrm{P} \leq 0.01$ and $\mathrm{P} \leq 0.05$, respectively. Y: Year, ST: Sowing time, CS: Cutting stage

\section{Neutral detergent fibre}

Year $\mathrm{x}$ sowing time interaction was found to be significant for neutral detergent fibre (NDF) content at $1 \%$ significance level. The highest NDF ratio was determined in the plants sown on March 15, 2017 and the lowest ratio was in the plants sown on April 15, 2017 (Figure 4). In the present study, while the NDF content was decreased continuously as the sowing time delayed in 2017 , it was decreased slightly in 2018 , then increased and decreased again during the last sowing period. In addition, in the third sowing period, while NDF content was decreased by $8.62 \%$ in 2017 , increased by $6.70 \%$ in 2018 . For these reasons, year $\mathrm{x}$ sowing time interaction was significant. It can be said that considerable variations in plant heights, especially over the last three sowing periods $(57.98 \%$ decrease in $2017,3.52 \%$ decrease in 2018), may be causing this situation (Figure 1). In general, plants tend to reach to cutting maturity without showing a sufficient height and stem development with the increase of air temperature in late sowings. Therefore, stem/leaf ratio in late sowings may be lower than that of in early sowings. This led to the formation of less fibrous compounds in the late sowings and thus NDF ratios were found low. Because the NDF content, which consists of a combination of structural carbohydrates such as cellulose, hemicellulose and lignin, has an important relationship with the stem/leaf ratio in plants (Onal Asci and Acar, 2018). As a matter of fact, the stem /leaf ratio increases as the plant height increases and this increase causes the NDF content to increase (Buxton, 1996).

Sowing time $\mathrm{x}$ harvesting time interaction was found to be statistically significant for NDF ratio at $5 \%$ significance level (Figure 4). In this study, the highest NDF content was obtained in the plots sown in the first period and harvested in the late period, while the lowest NDF content was obtained from the plots sown in the late period and harvested in the first period. In comparison to the previous sowing periods, NDF content was decreased by $4.87 \%$ and $2.87 \%$, respectively, in the second and third harvest periods in the plants sown in the third period while it was increased by $4.82 \%$ in the first harvest. This may be a reason for the significance of sowing time $\mathrm{x}$ harvest time interaction. In general, plants sown early and harvested late have a longer vegetation period and benefit more from environmental factors such as water, light and nutrients. As a result, the stems are thicker and structural carbohydrate deposits such as cellulose and lignin will be higher in the cell walls (Kacar et al., 2006). Hence, Uke (2016) reported that the NDF content which forms the cell wall components in the quinoa plant increases depending on the harvest time.

\section{Acid detergent fibre}

The effect of year $\mathrm{x}$ sowing time interaction on acid detergent fibre (ADF) was found to be significant at $1 \%$ (Figure 5). The highest ADF content was determined in the first sowing in 2017 and the lowest rate was found in the fourth sowing in 2017. In 2017, ADF content was decreased continuously as the sowing time was delayed. However, in the first two sowing periods in 2018, the ADF ratio did not change, then increased slightly and later remained constant. In addition, ADF content was decreased by $13.66 \%$ in the third sowing period compared to the previous sowing period in 2017 , but increased by $6.96 \%$ in 2018. This change in ADF content depending on the years and sowing times caused the interaction of year $\mathrm{x}$ sowing time to be significant. These changes in ADF content may be due to the differences in plant height according to years and sowing times. In this study, it was observed that plant height was decreased with the delay in sowing in 2017, whereas in 2018 there was no decrease in plant height (Figure 1). In general, height increase in plants causes an increase in stem / leaf ratio, which increases the amount of structural carbohydrates such as cellulose and lignin (ADF) (Buxton, 1996). 

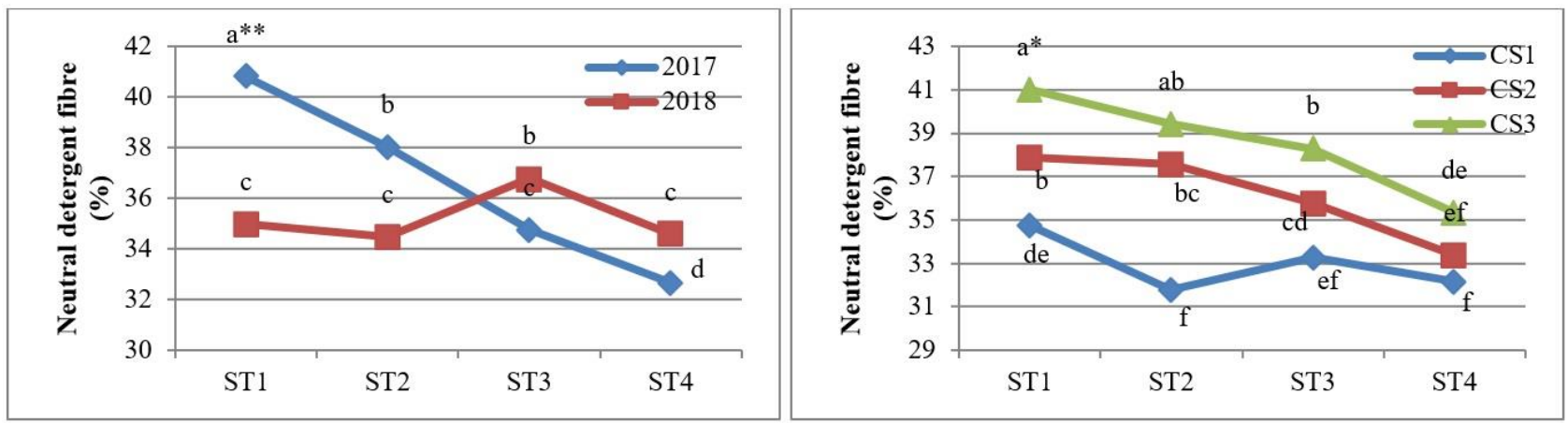

Figure 4. The effect of Y x ST and ST x CS interaction on the neutral detergent fibre. ** and * plots followed by the different letters are significant at $\mathrm{P} \leq 0.01$ and $\mathrm{P} \leq 0.05$, respectively. Y: Year, ST: Sowing time, CS: Cutting stage

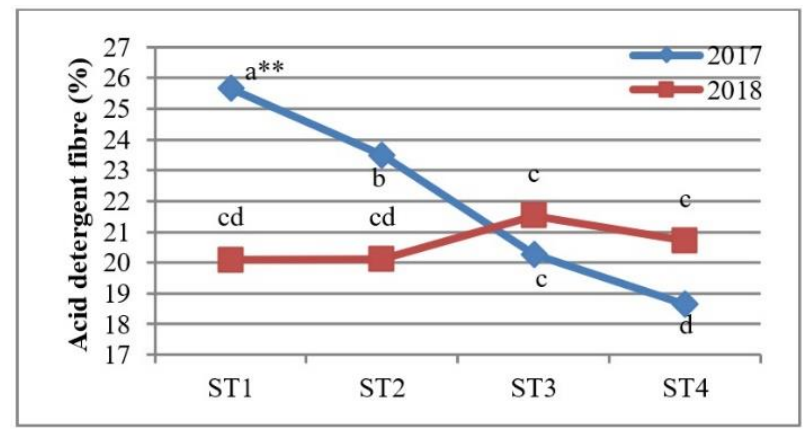

Figure 5. The change in acid detergent fibre according to sowing times and years. $*$ plots followed by the different letters are significant at $\mathrm{P} \leq 0.01$. ST: Sowing time

\section{Dry matter digestibility}

In terms of dry matter digestibility, year $\mathrm{x}$ sowing time interaction was significant $(\mathrm{P} \leq 0.05)$. The highest dry matter digestibility was determined at the fourth sowing time in 2017 and the lowest value was found at the first sowing time in 2017 (Figure 6). While the dry matter digestibility increased by $3.54 \%$ in 2017 , it decreased by $1.50 \%$ in 2018 compared to the previous sowing period. This difference resulted in the significance of interaction of the year $\mathrm{x}$ sowing time. In general, plants can grow to cutting maturity without showing sufficient growth (vegetative growth) since they are exposed to low rainfall, high temperature and light conditions in late sowings. This leads to the formation of thinner stems, increased leaf / stem ratio and increased digestibility (Onal Asci and Acar, 2018). Due to these reasons, dry matter digestibility may have increased in 2017 due to the increase in sowing time. However, the higher amount of precipitation in 2018, especially in May and June compared to the same months of 2017 (Table 1), may have caused the plants to grow in length and have thicker stems. This resulted in a reduced rate of dry matter digestibility with the delay in sowing time in 2018.

\section{Relative feed value}

In the study, the effect of triple interactions on relative feed value (RFV) showed a statistically significant difference at 5\% significance level (Table 3). When Table 3 was examined; the highest relative feed value was obtained from the plots sown in the last week of March
2018 and harvested at the end of the vegetative period. The lowest value was obtained from the plots sown in mid-March 2017 and harvested at the last period. In general, the rate of increase in RVF was higher in 2017 than in 2018 as the sowing time was delayed and the harvest was taken early. In addition, in the second sowings, RVF increased by $11.26 \%$ and $2.22 \%$ in the first and third harvests of 2018, respectively, and decreased by $6.47 \%$ in the second harvest, in comparison to the first sowings. This resulted in significant interaction between year $\mathrm{x}$ sowing time $\mathrm{x}$ harvest time. RFV is a numerical measure of feed quality that is calculated using NDF and ADF values. If RFV is below 75, the feed is accepted as $5^{\text {th }}$ quality, while feed with 75-86 RFV score is considered as $4^{\text {th }}$ quality, $87-102$ is $3^{\text {rd }}$ quality, $103-124$ is $2^{\text {nd }}$ quality, $125-150$ is $1^{\text {st }}$ quality and above 150 is considered the best quality (Rohweder et al., 1978). Therefore, it is desirable that these two values (NDF and ADF) be low for RFV to be high. In this study, NDF and ADF ratios of the plants that were sown at the end of March 2018 and harvested at the end of the vegetative period were found to be quite low compared to other sowing and harvesting periods.

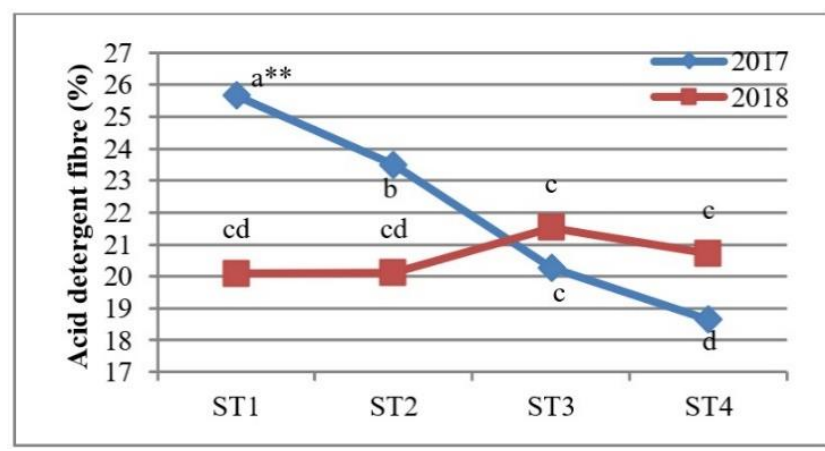

Figure 6. The change in dry matter digestible according to sowing times and years. Plots followed by the different letters are significant at $\mathrm{P} \leq 0.01$. ST: Sowing time

According to the two-year average results, it was seen that yield and quality characteristics of quinoa grown for hay production were significantly affected by different sowing and harvesting periods. Accordingly, in order to obtain high hay yield and quality performance in quinoa, it was demonstrated that sowings should be done at the first opportunity in spring and harvestings should be done at a later period. In addition, it has been seen that when 
cultivated during the appropriate sowing and harvesting periods, quinoa gives a considerably high yield and highquality hay production and can be an important alternative feed source for closing the roughage gap.

\section{ACKNOWLEDGEMENTS}

The first year of this study was supported by Igdir University Department of Scientific Research Projects (Project Number: 2017-FBE-L07). We would like to thank the BAP council for their contribution to this study.

\section{LITERATURE CITED}

Aguilar, P.C. and S.E. Jacobsen. 2003. Cultivation of quinoa on the peruvian altiplano. Food Rev. Int. 19: 31-41.

Anonymous. 2019. Igdir provincial directorate of meteorology. Igdir, Turkey.

AOAC. 1997. Official Methods of Analysis. Association of Official Analytical Chemists. 16. ed. 3. revision. Arlington, VA, USA.

Bazile, D. and F. Baudron. 2015. The dynamics of the global expansion of quinoa growing in view of its high biodiversity. In: State of the Art Report of Quinoa in the World in 2013, ed. Bazile, D., D. Bertero and C. Nieto, 42-55, FAO \& CIRAD, Rome.

Bertero, H.D. and R.A. Ruiz. 2010. Reproductive partitioning in sea level quinoa (Chenopodium quinoa Willd.) cultivars. Field Crops Res. 118: 94-101.

Bhargava, A., S. Shukla and D. Ohri. 2006. Chenopodium quinoa. An Indian perspective. Ind Crops Prod. 23: 73-87.

Buxton, D.R. 1996. Quality related characteristics of forages as influenced by plant environment and agronomic factors. Anim. Feed Sci. Technol. 40: 109-119.

Cakmakci, S. and S. Temel. 2019. Selection studies for the development of seed type quinoa (Chenopodium quinoa Willd.) lines. Int. J. Agric. Wildlife Sci. 5: 335-345.

Casini, P. 2019. Seed yield of two new quinoa (Chenopodium quinoa Willd.) breeding lines as affected by sowing date in Central Italy. Acta Agric Slov. 113: 51-62.

Cusack, D.F. 1984. Quinoa: grain of the incas. The Ecologist. 14: $21-30$

FAO. 1994. Plant production and protection series. In: Neglected crops from a different perspective, ed. Hernandez, J.E. and J. Leon, No. 26, http://www.fao.org/ docrep/T0646E/T0646E00.htm, (Accessed 04, 2018).

Fernando, S.V., S.V. Edmar, G.B. Marcelo and S. Lucas. 2012. Development and productivity of quinoa sown on different dates during off-season. Rev Cienc Agron. 43: 510-515.

Galwey, N.W. 1989. Exploited plants - quinoa. Biologist. 36: 267-274.

Geren, H. 2015. Effect of different nitrogen levels on the grain yield and some yield components of quinoa (Chenopodium quinoa willd.) under Mediterranean climatic conditions. Turkish J. Field Crops. 20: 59-64.

Geren, H. and O. Alan. 2012. Effects of different sowing dates on the herbage yield and some other yield characteristics of two pea (Pisum sativum L.) cultivars. ANADOLU J. of AARI. 22: 37-47.

Geren, H., Y.T. Kavut, G.D. Topcu, S. Ekren and D. Istipliler. 2014. Effects of different sowing dates on the grain yield and some yield components of quinoa (Chenopodium quinoa willd.) grown under Mediterranean climatic conditions J. Ege University Faculty of Agriculture 51: 297-305.

Gokkus, A. 2009. Ecology and physiology of forage crops. In: Forage Crops, ed. Avcioglu, R., R. Hatipoglu and Y. Karadag. Ministry of Agriculture and Rural Affairs Puplications. 1(3):65-119, Ankara.
González, J.A., M. Gallardo, M. Hilal, M. Rosa and F.E. Prado. 2009. Physiological responses of quinoa (Chenopodium quinoa) to drought and waterlogging stresses: dry matter partitioning. Bot Stud. 50: 35-42.

Gulsen, N., B. Coskun, H.D. Umucalılar and H. Dural. 2004. Prediction of nutritive value of a native forage, prangos uechritzii, using of in situ and in vitro measurements. J. Arid Environ. 56: 167-179.

Hirich, A., R. Choukr-Allah and S.E. Jacobsen. 2014. Quinoa in Morocco - Effect of sowing dates on development and yield. J Agron Crop Sci. 200:371-377.

Jacobsen, S.E., A. Mujica and R.C. Jensen. 2003. The resistance of quinoa (Chenopodium quinoa Willd.) to adverse abiotic factors. Food Rev. Int. 19: 99-109.

Jacobsen, S.E., B. Jørnsgård, J.L. Christiansen and O. Stølen. 1999. Effect of harvest time, drying technique, temperature and light on the germination of quinoa (Chenopodium quinoa). Seed Sci. Technol. 27: 937-944.

Jacobsen, S.E. and O. Stolen. 1993. Quinoa- morphology, phenology and prospects for its production as a new crop in Europe. Eur J Agron. 2: 19-29.

Kacar, B. 2012. Soil Analysis. Ankara: Nobel Publication Distribution.

Kacar, B., A.V. Katkat and S. Ozturk. 2006. Plant Physiology. 2. ed. Ankara: Nobel Publication Distribution.

Kir, A.E. and S. Temel. 2016. Determination of seed yield and some agronomical characteristics of different quinoa (Chenopodium quinoa Willd.) variety and populations under dry conditions of Igdir Plain. Igdır Univ. J. Inst. Sci. \& Tech. 4: $145-154$

Kir, A.E. and S. Temel. 2017. Determination of seed yield and some agronomical characteristics of different quinoa (Chenopodium quinoa Willd.) genotypes under irrigated conditions. Igdir Univ. J. Inst. Sci. \& Tech. 7: 353-361.

Krivonos, E. 2013. Food Outlook: Biannual Report on Global Food Markets, FAO. Trade and Markets Division, Rome, Italy.

Kutlu, H.R. 2008. Feed Evaluation and analysis methods. Lecture notes. http://www.zootekni.org.tr/upload/File/sunular/tm.pdf, (Accessed June 20, 2017).

Martínez, E.A. 2015. Quinoa: Nutritional Aspects of the Rice of the Incas. Section 3. Nutritional and technical aspects In: Bazile D, Bertero D and Nieto C (Eds.). FAO and CIRAD, Rome. State of the Art Report of Quinoa in the World in 2013, pp. 278-285.

Munir, H. 2011. Introduction and Assessment for Quinoa (Chenopodium quinoa Willd.) as a Potential Climate Proof Grain Crop. Ph D thesis, University of Agriculture, Faisalabad.

Onal Asc1, O. and Z. Acar. 2018. Quality of Roughage. Yenimahalle/Ankara: Positive Printing and Packaging Industry Trade Company.

Pearsall, D.M. 1992. The origins of plant cultivation in South America. In: The Origins of Agriculture, ed. C.W. Cowan, P.J. Watson, 73-205, Smithsonian Institute Press, Washington, DC.

Ramesah, K. 2016. Evaluation of Quinoa (Chenopodium quinoa willd.) at Different Dates of Sowing and Varied Crop Geometry in Semi-arid Regions of Telangana. Professor Jayashankar Telangana State Agricultural University. Master of Science in Agriculture, Telangana, India.

Risi, J.C. and N.W. Galwey. 1991. Effects of sowing date and sowing rate on plant development and grain yield of quinoa (Chenopodium quinoa) in a temperate environment. J Agri. Sci. 117: 325-332. 
Rohweder, D.A., R.F. Barnes and N. Jorgensen. 1978. Proposed hay grading standards based on laboratory analyses for evaluating quality. J Anim Sci. 47: 747-759.

Sanchez, H.B., R. Lemeur, P. Van Damme and S.E. Jacobsen. 2003. Ecophysiological analysis of drought and salinity stress of quinoa (Chenopodium quinoa Willd.). Food Rev. Int. 19: 111-119.

Sheaffer, C.C., M.A. Peterson, M. Mccalin, J.J. Volene, J.H. Cherney, K.D. Johnson, W.T. Woodward and D.R. Viands. 1995. Acide detergent fiber, neutral detergent fiber concentration and relative feed value. North American Alfalfa Improvemnt Conference, Minneapolis.

Sigsgaard, L., S.E. Jacobsen and J.L. Christiansen. 2008. Quinoa, Chenopodium quinoa, provides a new host for native herbivores in northern Europe: Case studies of the moth, Scrobipalpa atriplicella, and the tortoise beetle, Cassida nebulosa. J. Insect Sci. 8: 1-4.

Tan, M. and S. Temel. 2017a. Studies on the adaptation of quinoa (Chenopodium quinoa Willd.) to Eastern Anatolia Region of Turkey. Agrofor Int. J. 2: 33-39.

Tan, M. and S. Temel. 2017b. Determination of dry matter yield and some properties of different quinoa genotypes grown in Erzurum and Igdir conditions. Igdir Univ. J. Inst. Sci. \& Tech. 7: 257-263.
Tan, M. and S. Temel. 2018. Performance of some quinoa (Chenopodium quinoa Willd.) genotypes grown in different climate conditions. Turkish J. Field Crops. 23:180-186.

Tan, M. and S. Temel. 2019. Quinoa in Every Aspect: Importance, Use and Cultivation. Ankara, Turkey: IKSAD Publishing House.

Temel, S. and M. Tan. 2002. A research on determination of seeding and cutting time in common vetch (Vicia sativa L.) under Erzurum conditions. Ataturk Univ. J. of the Agricultural Faculty. 33: 363-368.

Temel, S. and N. Surgun. 2019. The Effect of different nitrogen and phosphorus doses on hay yield and quality of quinoa. Igdir Univ. J. Inst. Sci. \& Tech. 9: 1785-1796.

Uke, O. 2016. Effects of Harvest times on herbage yield and quality of quinoa and teff plants. Erciyes University Institute of Natural and Applied Sciences, Department of Field Crop, Graduate Thesis, Kayseri.

Van Schooten, H.A. and J.B. Pinxterhuis. 2003. Quinoa as an alternative forage crop in organic dairy farming. Optimal Forage Systems for Animal Production and the Environment Grassland Science in Europe, Vol: 8.

Van Soest, P.J., J.D. Robertson and B.A. Lewis. 1991. Methods for diatery fibre, neutral detergent fibre and non-starch polysaccharides in relation to animals nutrition. J. Dairy Sci. 74: 3583-3597. 